\title{
Optimalisasi Pengembangan Produk Unggulan Desa (Ovop) Melalui Wawasan Kewirausahaan Dan Pembuatan Laporan Keuangan Sederhana Bagi UMKM
}

\author{
Neni Nurhayati \\ neninurhayati@uniku.ac.id \\ Dosen Prodi Akuntansi, Universitas Kuningan
}

\begin{abstract}
ABSTRAK
Besarnya potensi UMKM ternyata tidak serta merta menyebabkan UMKM mampu mengembangkan potensi usahanya. Kendala utama yang sering muncul adalah keterbatasan modal yang dimiliki serta kesulitan dalam memperoleh akses sumber permodalan misalnya ke perbankan dan sumber pembiayaan lainnya. Rendahnya kualitas sumber daya manusia yang dimiliki UMKM membuat mereka sering terjebak dengan sumber-sumber dana informal, yang sekali lagi disebabkan oleh kerumitan persyaratan pemenuhan dana yang bersumber dari sektor keuangan formal. Salah satu dari persyaratan yang paling sulit untuk dilengkapi adalah persyaratan untuk melampirkan laporan keuangan usaha. Kemudahan akses modal perbankan dapat diperoleh apabila para pelaku UMKM dapat memberikan rincian informasi mengenai keadaan usaha UMKM yang tercermin pada laporan keuangannnya. Peraturan Pemerintah RI No 17 Tahun 2013 tentang pelaksanaan UU No 20 tahun 2008 menyatakan adanya kewajiban bagi usaha kecil untuk melakukan pencatatan akuntansi. Namun demikian, adanya peraturan tersebut tidak serta merta membuat pelaku UMKM melakukan pencatatan dikarenakan berbagai keterbatasan. Tujuan pelaksanaan pengabdian kepada masyarakat ini adalah untuk memberikan pemahaman, pengetahuan dan wawasan mengenai berwirausaha dengan mengembangkan potensi desa serta memberikan pendampingan dalam implementasi sistem pencatatan akuntansi manual dengan melakukan aktivitas pembuatan laporan keungan sederhana untuk memberikan kemudahan mendapatkan akses permodalan dari perbankan. Metode pengabdian yang digunakan yaitu ceramah, workshop, praktik, dan evaluasi kegiatan. Hasil dari pengabdian kepada masyarakat ini berupa pengembangan produk unggulan desa (OVOP) dan keterampilan pembuatan laporan keuangan sederhana.
\end{abstract}

Kata Kunci: OVOP, kewirausahaan, laporan keuangan,

\section{PENDAHULUAN}

Desa Genteng merupakan desa pemekaran dari Kecamatan Talaga yang kini menjadi bagian dari Kecamatan Banjaran sehingga Desa Genteng kini masuk ke dalam Kecamatan Banjaran. Desa Genteng merupakan desa terakhir di Kecamatan Banjaran dan bukan merupakan desa adat sehingga masyarakatnya pun kurang begitu tahu, bagaimana sejarah berdirinya Desa Genteng. Desa Genteng dipimpin oleh Kepala Desa yang dibantu oleh perangkat desa. Perangkat desa terdiri dari Badan Permusyawaratan Desa, Sekretaris Desa, Bagian Urusan Ekonomi dan Pembangunan, Bagian Kesejahteraan Rakyat, Urusan Umum, Urusan Pemerintahan, Pulisi Desa, Pamong Tani Desa, dan Kepala Dusun.

Desa Genteng memiliki luas kurang lebih 125 ha dan didominasi oleh daerah pesawahan sekitar 75 ha. Desa Genteng terbagi menjadi 3 Dusun dan 6 Blok yaitu Dusun Desa terdiri dari Blok Desa, Blok Hantap, dan Blok Cililin, Dusun Cikandang terdiri dari Blok Cililin dan Blok Pasanggrahan, dan Dusun Cikandang terdiri dari Blok Cikandang. Wilayah Desa 
Genteng berbatasan dengan Desa Hegarmanah (Utara), Desa Darmalarang dan Desa Sunia Baru (Timur), Desa Ganeas (Selatan), dan Desa Talaga Wetan (Barat).

Wilayah Desa Genteng Kecamatan Banjaran Kabupaten Majalengka merupakan daerah agraris. Kegiatan ekonomi dan mata pencaharian sebagian besar penduduknya adalah petani dan berwirausaha. Berikut data matapencaharian penduduk Desa Genteng:

Tabel 1 Mata pencaharian Penduduk Desa Genteng

\begin{tabular}{|l|l|l|}
\hline Jenis Pekerjaan & Laki - Laki & Perempuan \\
\hline Petani & 214 orang & 212 orang \\
\hline Buruh Tani & 13 orang & 1 orang \\
\hline Montir & 5 orang & 0 orang \\
\hline TNI & 1 orang & 0 orang \\
\hline POLRI & 4 orang & 0 orang \\
\hline Seniman/Artis & 7 orang & 8 orang \\
\hline Pedagang Keliling & 5 orang & 20 orang \\
\hline Pembantu Rumah Tangga & 0 orang & 5 orang \\
\hline Karyawan Swasta & 10 orang & 6 orang \\
\hline Pensiunan & 10 orang & 6 orang \\
\hline Belum Bekerja & 260 orang & 243 orang \\
\hline Buruh Harian Lepas & 10 orang & 0 orang \\
\hline Ibu Rumah Tangga & 0 orang & 603 orang \\
\hline Karyawan Honorer & 6 orang & 12 orang \\
\hline Jumlah Total & 1.661 Orang & \\
\hline
\end{tabular}

Kantor Pemerintah Desa Genteng (2018)

Dari tabel diatas terlihat bahwa sebagian besar penduduknya adalah petani dan berwirausaha. Namun sayangnya besarnya potensi UMKM ternyata tidak serta merta mampu menyebabkan UMKM mampu mengembangkan potensi usahanya. Kendala utama yang sering muncul adalah masyarakat setempat kurang mampu menggali potensi sumberdaya yang ada untuk dijadikan sumber penghasil dalam berwirausaha, selain itu bagi UMKM yang sudah adapun masih dihadapkan pada kendala seperti keterbatasan modal yang dimiliki serta kesulitan dalam memperoleh akses sumber permodalan misalnya ke perbankan dan sumber pembiayaan lainnya. Padahal UMKM saat ini tengah dihadapkan dengan adanya Masyarakat Ekonomi ASEAN (MEA), dimana para pelaku usaha dituntut untuk mampu bersaing dalam pasar bebas yang lebih luas. Pelaku UMKM dituntut untuk mampu lebih berinovasi dan kreatif dalam menciptakan produk serta mengembangkan usahanya. Hal tesebut tentu saja membutuhkan biaya yang besar serta permodalan yang kuat.

Sejauh ini sebagian besar pelaku UMKM hanya menggunakan modal yang berasal dari diri sendiri karena usaha kecil yang dijalankan hanya untuk memenuhi kebutuhan hidup keluarga sehari-sehari, sehingga adanya pinjaman terhadap bank hanya akan menjadi beban dan bukan meenjadi faktor pendorong peningkatan usaha UMKM. Selain itu, kendala yang dihadapi para pelaku UMKM adalah dikarenakan persyaratan yang rumit yang diberikan oleh pihak pemberi kredit dalam mendapatkan akses permodalan. Rendahnya kualitas sumber daya manusia yang dimiliki UMKM membuat mereka sering terjebak dengan sumber-sumber dana informal, yang sekali lagi disebabkan oleh kerumitan persyaratan pemenuhan dana yang bersumber dari sektor keuangan formal. Salah satu dari persyaratan yang paling sulit untuk dilengkapi adalah persyaratan untuk melampirkan laporan keuangan.

Kemudahan akses modal perbankan dapat diperoleh apabila para pelaku UMKM dapat memberikan rincian informasi mengenai keadaan usaha UMKM yang tercermin pada laporan 
keuangannnya. Peraturan Pemerintah RI No 17 Tahun 2013 tentang pelaksanaan UU No 20 tahun 2008 menyatakan adanya kewajiban bagi usaha kecil untuk melakukan pencatatan akuntansi. Namun demikian, adanya peraturan tersebut tidak serta merta membuat pelaku UMKM melakukan pencatatan.

Berdasarkan permasalahan di atas penulis tertarik untuk melakukan program pengabdian kepada masyarakat dengan tema "Optimalisasi Pengembangan Produk Unggulan Desa (OVOP) Melalui Wawasan Kewirausahaan Dan Pembuatan Laporan keungan Sederhana Bagi Umkm di Wilayah Desa Genteng Kecamatan Banjaran Majalengka “. Hal ini sesuai dengan tri darma perguruan tinggi yang harus melaksanakan pengajaran, penelitian dan pengabdian. Selain itu, hal ini sesuai dengan visi Universitas Kuningan, menjadi universitas unggul yang memiliki komitmen tinggi terhadap pemberdayaan masyarakat pada tahun 2023 .

\section{Permasalahan Mitra}

Besarnya potensi UMKM di Desa Genteng tidak serta merta menyebabkan UMKM mampu mengembangkan potensi usahanya. Kendala utama yang sering muncul adalah masyarakat setempat kurang mampu menggali potensi sumberdaya yang ada untuk dijadikan sumber penghasil dalam berwirausaha, selain itu bagi UMKM yang sudah adapun masih dihadapkan pada kendala seperti keterbatasan modal yang dimiliki serta kesulitan dalam memperoleh akses sumber permodalan misalnya ke perbankan dan sumber pembiayaan lainnya karena keterbatasan dalam membuat laporan keuangan.

\section{Solusi}

Dalam kegiatan pengabdian kepada masyarakat berkaitan dengan pengembangan UMKM di wilayah Desa Genteng, terdapat beberapa solusi yang dapat diberikan yaitu:

1. Memberikan pemahaman, pengetahuan dan wawasan mengenai berwirausaha dengan mengembangkan potensi desa

2. Memberikan pendampingan dalam implementasi sistem pencatatan akuntansi manual dengan melakukan aktivitas pembukuan sederhana untuk memberikan kemudahan mendapatkan akses permodalan dari perbankan.

\section{METODE PELAKSANAAN}

Berdasarkan permasalahan di atas, maka metode pelaksanaan kegiatan yang digunakan dalam kegiatan ini menggunakan metode antara lain:

1. Sosialisasi (penyuluhan) tentang wirausaha dengan mengembangkan potensi desa

2. Sosialisasi pemahaman keuangan pada aktivitas usaha UMKM.

3. Demonstrasi produk unggulan potensi desa yang bisa dikembangkan menjadi OVOP

4. Pendampingan pembuatan laporan keuangan sederhana yang dilakukan dengan pendekatan individual terhadap setiap pelaku UMKM tentang bagaimana melakukan pembukuan dari proses pengenalan akun lalu kemudian berkenalan dengan bagaimana mencatat transaksi dan menjurnal sampai pada pembuatan laporan keuangan sederhana.

5. Pelatihan dan evaluasi

Metode ini digunakan untuk memberikan latihan kepada peserta pendampingan untuk mempraktikan pencatatan dan pembukuan sederhana dari proses pendampingan dilanjut dengan aktivitas latihan. Setelah dirasa paham, perlu juga dilakukan evaluasi untuk memastikan tersampaikannya materi dan informasi yang sudah diberikan dalam aktivitas sosialisasi ini terhadap setiap pelaku UMKM yang terlibat. 


\section{Peserta Pengabdian}

Peserta yang ikut dalam kegiatan pengabdian kepada masyarakat adalah UMKM di Desa Genteng Majalengka. Adapun peserta berjumlah 40 orang.

\section{Waktu dan tempat Kegiatan}

Waktu kegiatan pengabdian masyarakat ini dilaksanakan pada tanggal 5 sampai dengan tanggal 7 Desember 2018 bertempay di Balai Desa Genteng Majalengka.

\section{HASIL DAN PEMBAHASAN}

Kegiatan Pengabdian kepada Mayarakat $(\mathrm{PkM})$ telah dilakukan selama 3 (tiga) hari dimulai tanggal 5 sampai dengan tanggal 7 Desember 2018. Kegiatan tersebut berjalan lancar dan sesuai dengan yang telah ditargetkan sebelumnya. Antusiasme masyarakat terlihat begitu jelas dengan dibuktikan masyarakat yang hadir pada saat itu sebanyak 37 orang dari 40 peserta yang diundang. Selama kegiatan berlangsung terlihat keaktifan dari masyarakat dalam merespon berbagai kajian yang kami bawakan baik itu menjawab pertanyaan atau mengajukan pertnyaan. Dalam kegiatannya kamipun telah mempersiapkan beberapa souvenir sebagai rewards bagi peserta yang aktif selama kegiatan berlangsung.

Gambar 1. Narasumber dan Keaktifan peserta dalam kegiatan PkM di Desa Genteng

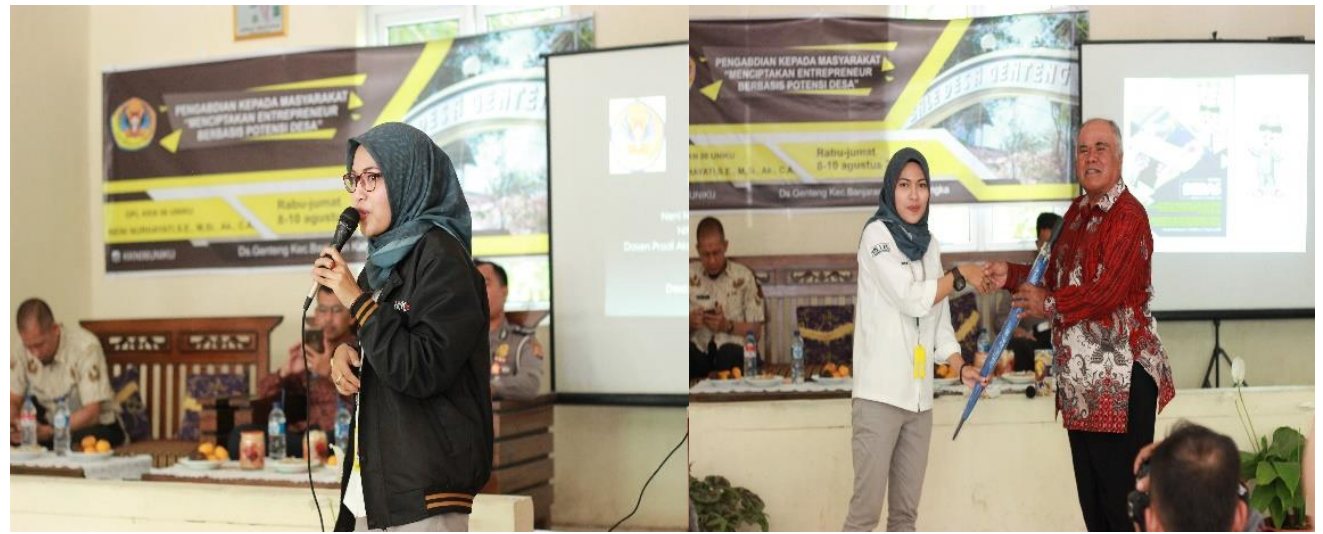

Kegiatan PkM ini dilakukan dengan tiga tahap yaitu tahap pertama memberikan sosialisasi/penyuluhan terkait dengan pemahaman berwirausaha dengan berbasis pada potensi desa untuk menciptakan OVOP, tahap ke dua memberikan sosialisasi/penyuluhan mengenai strategi pemasaran dan pengembangan produk olahan berbasis potensi desa, sedangkan tahap ketiga yaitu memberikan penyuluhan dan pendampingan dalam implementasi sistem pencatatan akuntansi manual dengan melakukan aktivitas pembukuan sederhana untuk memberikan kemudahan mendapatkan akses permodalan dari perbankan.

Adapun ketiga tahap tersebut dapat dijelaskan sebagai berikut:

\section{Tahap Pertama}

Pada tahap ini metode yang dilakukan yaitu metode ceramah, diskusi, dan tanya jawab. Pada tahap ini disajikakan terkait dengan pemahaman berwirausaha dengan berbasis pada potensi desa untuk menciptakan OVOP. Adanya OVOP tersebut diharapkan akan mampu 
meningkatkan kesejahteraan masyarakat desa setempat. Berdasarkan situasi/kondisi desa diawal teridentifikasi bahwa masyarakat di desa Genteng masih minim terkait penciptaan produk olahan yang bisa dikembangkan dari potensi desa yang tersedia. Dalam kgiatan inipun dijelaskan terkait penciptaan desa mandiri, penciptaan OVOP, manfaat berwirausaha, tips menciptakan produk unggulan baru, dan lain sebagainya. Dalam tahap ini peserta mampu memperoleh pemahaman yang luas terkait peluang yang dapat diperoleh untuk mengembangkan produk baru yang diciptakan sebagai media dalam meningkatkan kesejahteraan keluarga. Dengan penciptaan produk baru berdasarkan potensi desa tersebut maka akan secara langsung berdampak pada terciptanya desa mandiri yang mampu membuka peluang usaha sendiri dan tentunya akan mampu meningkatkan penyerapan tenaga kerja di desa tersebut. Adanya desa mandiri ini akan mampu memberikan brand image desa yang baik karena akan mampu menciptakan OVOP yang diharapkan mampu untuk mengangkat nilai dan eksistensi desa tersebut. Selama sesi pertama berlangsung, peserta terlihat antusisa mengikuti pemaparan pemateri, terlihat begitu antusias dan penasaran untuk menunggu sesi berikutnya dlaam demonstrasi pembuatan dan penciptaan OVOP berdasarkan pengembangan potensi desa di Desa Genteng.

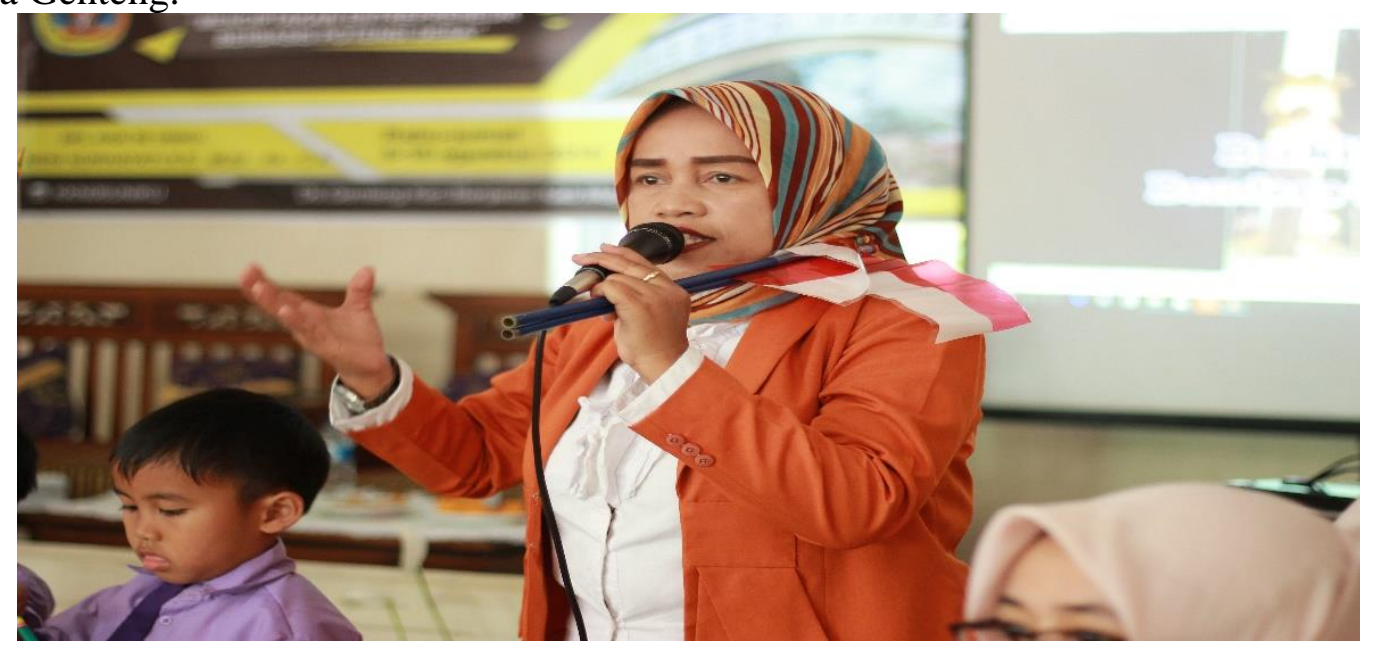

\section{Tahap Kedua}

Pada tahap kedua, metode yang dilakukan dengan cara diskusi, demonstasi dan tanya jawab. Pada tahap ini dijelaskan beberapa potensi yang dapat dijadikan produk olahan baru, penciptaan produk baru, cara pengemasan, cara pemasaran dan cara membuat produk olahan baru tersebut. Ada beberapa potensi yang dpat dikembangkan untuk menciptakan produk olahan baru diantaranya yaitu:

\section{Program Pengembangan Potensi Unggulan Desa Genteng}

Mengembangkan Budidaya Jamur

Pembudidayaan jamur di Desa Genteng cukup berkembang. Namun perkembangan tesebut tidak dibarengi dengan sumber daya manusia yang relevan, dan dalam pemasaran pun hanya terbatas pada bahan mentahnya saja. Maka dari itu, KKN kelompok kami ingin mengembangkan jamur mentah tersebut menjadi suatu produk yang lebih menarik untuk di pasarkan yaitu dengan membuat produk nugget jamur.

\section{Mengembangkan Produk Kripik Singkong}

Bahan baku kripik singkong tidak mudah didapatkan di Desa Genteng, tapi pada kenyataannya ada warga yang memproduksi kripik singkong. Namun dalam segi kemasan dan pemasaran 
masih kurang maksimal, sehingga kami berinisiatif untuk memberi sentuhan baru pada kemasan kripik singkong tersebut dan pemasaran dilakukan secara luas dengan media sosial.

Mengembangkan Produk Cireng Krispi

Di Desa Genteng ada warga yang dapat memproduksi cireng krispi yang bisa dibilang berbeda dengan cireng pada umumnya. Karena itu, kelompok kami berniat untuk lebih mengeksplor produk tersebut agar pemasarannya lebih luas.

\section{Program OVOP Desa Genteng}

Mengembangkan Produk Casablanka

Casablanka adalah makanan khas Desa Genteng yang terbuat dari singkong yang dimasak bersama dengan air santan, proses pembuatannya cukup lama sampai air sagunya keluar sehingga menghasilkan tekstur yang berkaca-kaca. Casablanka yang biasa diproduksi oleh masyarakat desa ini hanya dalam rasa original, maka mahasiswa KKN mengembangkan inovasi baru yaitu Casablanka dengan topping oreo susu, dengan inovasi ini diharapkan masyarakat bisa terus mengembangkan makanan ini sehingga bisa menjadi peluang usaha yang menjanjikan.

\section{Mengembangkan Produk Kripik Tempe}

Kripik tempe merupakan makanan yang banyak beredar dipasaran wilayah Majalengka salah satunya Desa Genteng, tidak sedikit masyarakat desa ini menjadikan makanan tersebut sebagai peluang usaha. Sehingga kami berinisiatif untuk memberi sentuhan baru pada kemasan kripik tempe tersebut dan pemasaran dilakukan secara luas dengan media sosial.

\section{Potensi Unggulan Desa Genteng}

Demonstrasi Casablanka

Casablanka merupakan produk makanan yang menjadi makanan favoritnya Bupati Majalengka yang pertama kali diperkenalkan oleh masyarakat Desa Genteng akan tetapi tidak banyak masyarakat desa ini yang mengenal bagaimana proses pembuatan Casablanka sehingga dengan adanya demonstrasi ini masyarakat menjadi tahu tentang keberadaan Casablanka sampai proses pembuatannya.

\section{Kerajinan Tangan dari Buah Berenuk}

Salah satu potensi dapat dikembangkan di Desa Genteng yaitu kerajinan dari buah berenuk yang dibuat oleh Kang Feri Cililin, adapun jenis-jenis kerajinannya yaitu tas, asbak dan tempat rokok, pulpen, gelang, cangklung, dan lain-lain. Akan tetapi buah berenuk tersebut sulit didapatkan, dan peminat kerjainan tersebut hanya orang tertentu saja. Karena itu, dengan dipamerkannya kerajinan tersebut di Expo akan dapat lebih mengekspos kerajinan tersebut.

Gambar 2. Produk olahan OVOP Desa Genteng 


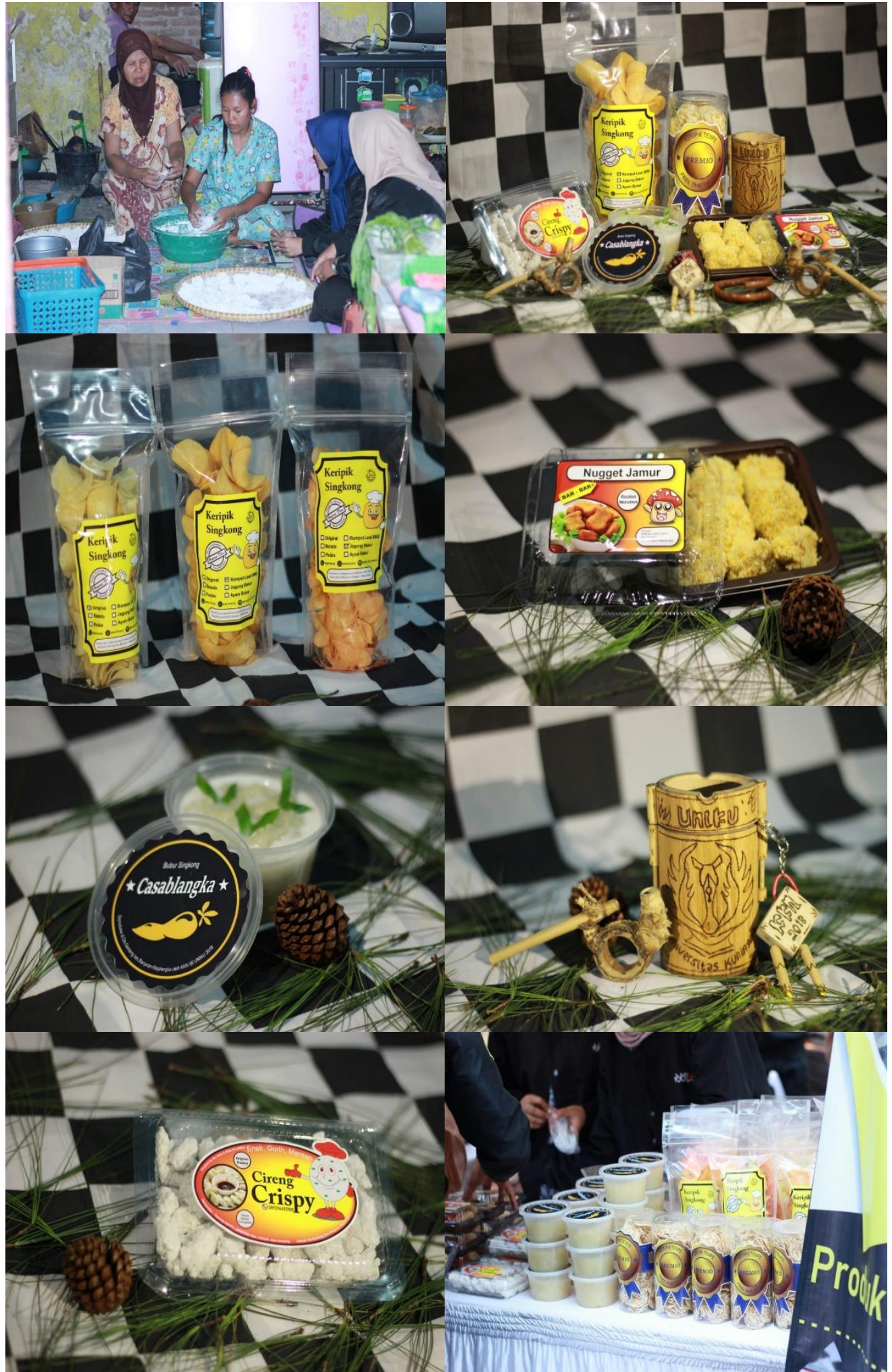

Tahap Ketiga

Output dari kegiatan PkM tahap ke tiga adalah membuat laporan keuangan sederhana. Adapun materi yang disampaikan antara lain: membuat perhitungan dari estimasi biaya 
dan pendapatan dari produksi makanan olahan OVOP dengan minimal sekali produksi , selain itu juga disajikan contoh membuat laporan keuangan. Berikut contoh perhitungannya:

\begin{tabular}{|c|c|c|}
\hline $\begin{array}{l}\text { Nama } \\
\text { Produk }\end{array}$ & Estimasi Biaya Produksi & Estimasi Penjualan \\
\hline $\begin{array}{l}\text { Casablank } \\
\text { a }\end{array}$ & $\begin{array}{l}\text { Singkong } 2 \mathrm{~kg} \times \mathrm{Rp} .12 .000= \\
\text { Rp } 24.000 \\
\text { Gula } 11 / 2 \mathrm{~kg} \text { Rp. } 18.000 \\
\text { Vanili Rp } 1.000 \\
\text { Kelapa Rp. } 10.000 \\
\text { Santan kara } 2 \times \mathrm{Rp} .3 .000= \\
\text { Rp. } 6.000 \\
\text { Sticker Rp. } 20.000 \\
\text { Cup } 10 \times \text { Rp. } 1.250=\mathrm{Rp} \\
12.500 \\
\text { Total biaya Rp. } \\
\text { 91.500 }\end{array}$ & $\begin{array}{l}\text { Harga Jual } 10 \text { x Rp. } 10.000=\text { Rp. } \\
100.000 \\
\text { Keuntungan dari } 10 \text { pcs = Rp. } \\
\text { 9.500,- }\end{array}$ \\
\hline
\end{tabular}

Di tahap 3 ini juga disampaikan pemaparan terkait contoh laporan keuangan sederhana yang bisa dibuat oleh para pelaku UMKM di desa setempat.

\section{Neraca}

Neraca menampilkan aset, kewajiban, dan ekuitas suatu entitas pada suatu tanggal tertentu akhir periode pelaporan. Neraca dapat dikatakan seimbang apabila harta perusahaan atau aset jumlahnya sama dengan jumlah utang ditambah modal.

\begin{tabular}{|c|c|c|c|}
\hline Asset & & Kewajiban Dan & Modal \\
\hline Aset Lancar & & Kewajiban & \\
\hline Kas & Rp. 5.000 .000 & Hutang usaha & Rp. 3.000 .000 \\
\hline Piutang Usaha & Rp. $\quad 1.000 .000$ & Hutang Bank & Rp. 8.000.000 \\
\hline Persediaan & Rp. $\quad 170.000$ & Jumlah Utang & Rp.11.000.000 \\
\hline Perlengkapan & $\begin{array}{ll}\text { Rp. } & 100.000\end{array}$ & & \\
\hline Jumlah Aset Lancar & Rp. 6.270.000 & & \\
\hline Aset Tetap & & Modal & \\
\hline Peralatan Masak & Rp. $\quad 500.000$ & Modal Disetor & $\begin{array}{l}\text { Rp. } 12.000 .000 \\
80.700 .000\end{array}$ \\
\hline Inventaris Pabrik & Rp. 2.000 .000 & & \\
\hline Akm.Penyusutan IP & $\begin{array}{ll}\text { Rp. } & (125.000)\end{array}$ & Laba sekarang & Rp.8.845.000 \\
\hline Kendaraan & Rp.15.000.000 & Prive & Rp.(2000.000) \\
\hline
\end{tabular}




\begin{tabular}{|l|l|l|l|}
\hline Akum.Penyusutan K & Rp. (2000.000) & Jumlah Modal & Rp. 18.845.000,- \\
\hline Bangunan & Rp. 10.000.000 & & \\
\hline Akum.Penyusutan B & Rp. (2.000.000) & & \\
\hline Inventaris Kantor & Rp. 200.000 & & \\
\hline Jumlah asset tetap & Rp. $\mathbf{2 3 . 5 7 5 . 0 0 0 , -}$ & & \\
\hline Total & Rp. 29.845.000 & Total & Rp. 29.845.000 \\
\hline
\end{tabular}

\section{Laporan laba/rugi}

Laporan laba rugi melaporkan pendapatan dan beban selama periode tertentu.

\begin{tabular}{|c|c|c|}
\hline Pendapatan & & \\
\hline Penjualan & 44.225 .000 & \\
\hline HPP & $(27.456 .250)$ & \\
\hline Laba Kotor & & Rp. 16.768.750,- \\
\hline Beban-Beban & & \\
\hline Beban listrik & Rp. 800.000 & \\
\hline Beban Telephon & Rp. $\quad 600.000$ & \\
\hline Beban Pengiriman & Rp. 1.120 .000 & \\
\hline Beban Sewa & 600.000 & \\
\hline Beban perlengkapan & 60.000 & \\
\hline Beban penyusutan & 343.750 & \\
\hline Beban gaji & $\begin{array}{ll}\text { Rp. } & 4.400 .000\end{array}$ & \\
\hline Jumlah Beban & & (Rp. 7.923.750,-) \\
\hline Laba Bersih & & Rp. 8.845.000,- \\
\hline
\end{tabular}

\section{Laporan Perubahan Ekuitas}

Laporan ekuitas pemilik melaporkan perubahan - perubahan yang terjadi pada ekuitas pemilik selama periode waktu tertentu. 


\begin{tabular}{|l|l|l|}
\hline Modal awal & & Rp. 12.000.000,- \\
\hline Penambahan & & \\
\hline Laba & $\begin{array}{l}\text { Rp. 8.845.000,- } \\
145.170 .000\end{array}$ & \\
\hline Pengurangan(Prive) & Rp. (2000.000) & \\
\hline Total Penambahan dan pengurangan & 73.900 .000 & Rp. 6.845.000,- \\
& & 71.270 .000 \\
\hline Modal akhir & & Rp. 18. 845.000,- \\
\hline
\end{tabular}

\section{KESIMPULAN DAN SARAN}

Pelaksanaan kegiatan pengabdian pada masyarakat dengan memberikan pendampingan pemahaman berwirausaha dengan mengembangkan potensi desa menjadi desa mandiri serta pembuatan laporan keuangan berlangung baik dan responsif. Hal ini terlihat dari dukungan dan antusias masyarakat para pelaku UMKM di Desa genteng dalam mengikuti kegiatan dari awal sampai akhir. Para peserta mampu memahami pentingnya kewirausahaan dengan menciptakan dan mengembangkan produk unggulan desa serta pemahaman dalam membuat laporan keuangan sederhana.

Pelaksanaan kegiatan pendampingan pemahaman berwirausaha dengan mengembangkan potensi desa menjadi desa mandiri serta pembuatan laporan keuangan perlu dilakukan kepada mitra lain yang tidak hanya berdomisili di Desa genteng saja tetapi pada seluruh warga masyarakat di desa lain agar mampu terciptanya desa mandiri yang memiliki OVOP masing masing sehingga setiap desa mampu meningkatkan kesejahteraan keluarga dengan berwirausaha mengembangakn potensi desanya masing-masing.

\section{DAFTAR PUSTAKA}

Anak Suryo, (2007). Akuntansi Untuk UKM, Metode akuntansi Praktis dan sederhana untuk Usaha Kecil dan Menengah, Media Pressindo.

LPPM. 2018. Panduan Pengabdian Kepada Masyarakat. Universitas Kuningan 